\title{
Visuaalne huumor internetis ${ }^{1}$
}

\begin{abstract}
Anneli Baran
Teesid: Internetikeel, sidudes kirjalikku ja suulist eneseväljendust, sisaldab endas visuaalseid elemente, mis muudab pildikeelest arusaamise üha olulisemaks. Üheks visuaalsuse näiteks on internetihuumorina käsitletavad fototöötlused, mis seovad endas verbaalse ja pildilise elemendi. Ka kujundlikud väljendid on oma loomult piltlikud - asjaolu, mis soodustab fraseoloogia uudset kasutamist internetikeskkonnas. Artiklis käsitletaksegi visualiseerimise rolli kujundlikkuse mõistmisel. Vaatluse all on eestikeelses internetis leiduvad märkimisväärse visuaalse huumori osakaaluga meelelahutuslikud keskkonnad, kus viljeletakse ohtralt poliitilist satiiri, visualiseerides sageli poliitikutelt pärinevaid väljendeid.
\end{abstract}

Märksõnad: demotivaator, fraseoloogia, huumor, internet, visuaalsus

Kahtlemata on visualiseerimine ääretult mõjus ja tõhus vahend sõnumi (olgu siis informatiivse, meelelahutusliku vm) edastamiseks ja arvutite kasutuselevõtu tõttu koheldakse ekraanil ka tekstuaalseid üksusi visuaalsetena. Visualiseerimine aitab oluliselt kaasa keeleliste kujundite mõistmisele ehk neile tähenduste andmisele; sellele viitab kasvõi asjaolu, et kasutusele on võetud koguni termin visuaalne grammatika (Kress 2003). Interneti-ajastul, mis on toonud endaga uue keelekasutusviisi nimega internetikeel, tuleb lisaks paljuräägitud kirjaliku ja suulise segunemisele üha enam arvestada kirjapildi graafilisuse-aspektiga (Crystal 2006: 19). Netikeskkonnas on võrdselt olulised nii see, mida tehakse, kui ka see, kuidas seda tehakse. Järgnevas keskendun eestikeelses internetis leiduva põhjal ainult mõnele minu kui fraseoloogiauurija arvates huvipakkuvamale kujundlikkuse mõistmist, visualiseerimist ja huumorit ühendavale ilmingule.

Suur osa internetis toimuvast ei ole muud, kui visuaalne kommunikatsioon, mida on paraku veel vähe uuritud. Ühtpidi on seda võimalik selgitada nähtuste 
lühiajalisusega, teisalt üldise suundumusega omistada sellele kommunikatsioonitüübile profaanset varjundit, sest visuaalse kommunikatsiooni põhiliseks esinemiskohaks on olnud peaasjalikult massimeedia ja -kultuur (Laaniste 2005: 617). Lisaks eripärasele keelekasutusele ja teisenenud kommunikatsioonile (loomult enamasti multimodaalne), on ka arvutisuhtluse sisu erinev sellest, millega olime harjunud arvutieelsel ajastul.

Seoses interneti ainuomaste ilmingutega tavatsetakse rääkida internetimeemidest. Meemid on iseenesest infokogumid (ideed, tavad, kujundid vms), mis kultuurikeskkonnas levivad, paljunevad ja muteeruvad. Selle idee eestkõnelejad on Richard Dawkins ja Susan Blackmore. Viimane on arendanud meemiteooriat edasi, rõhutades, et meem on tegelikult parasiit, mille vastu pole võimalik võidelda ega seda hävitada (Blackmore 1999: 110-111). ${ }^{2}$

Internetimeemide all peetakse silmas sotsiaalses võrgustikus, blogides, ekirjadena vm kanalite kaudu levitatavaid meeme, need võivad esineda hüperlingi, video, pildi, veebilehe, mingi sõna/fraasi või sümboli kujul (Wikipedia). ${ }^{3}$ Seejuures võib meem populaarkultuuri ilmingule omaselt lühema või pikema aja jooksul levides ka muutuda või hoopis kaduda. Üheks selliseks näiteks omamoodi transformeerumisest on nähtus nimega demotivaatorid.

Algselt oli tegemist plakatitega, mida tavatseti kasutada koolides ja kontorites inimeste motiveerimiseks (motivational posters). Seda laadi postreid asuti aga internetikeskkonnas levitades parodeerivas võtmes muutma - sellest ka nimetus demotivaatorid (või ka fake motivational posters). Ühtlasi on tegemist millegagi, millel puudub autorlus kitsamas mõttes, seega võib neid määratleda folkloorsete ilmingutena. Lähemalt demotivaatoritest edapidi.

\section{Visualiseerimise rollist kujundlike väljendite mõistmisel}

Internetikeskkond on juba mõnda aega pakkunud fraseoloogidele huvi eeskätt fraseoloogiliste väljendite kontekstualiseerimise aspektist, st uuritakse, kuidas kasutavad tavalised keelekasutajad omakeelseid traditsioonilisi väljendeid netikeskkonnas. Siinkohal on ilmnenud ka inimeste endi huvi selle vastu, kuidas aitab ütluste piltlikkus lahti mõtestada nende sisu. Näitena toon siinkohal blogi nimega Vanasõnasõel eesti vanasõnades ja muudes traditsioonilistes ütlustes sisalduva kujundlikkuse ja loogika üle arutlemisest. Siingi on üritatud käsitletavat temaatikat visuaalselt ilmestada, milleks fraseologismi või vanasõna kujundlikkus/piltlikkus annab suurepärase võimaluse. Iseasi, millised on need olulised või esilduvad küljed, mida peetakse mõtestamisel olulisimaks. Ka see võib olla inimeseti erinev. 
Foto 1. Blogi "Vanasõnasõel" (http://propverb. blogspot.com/).

Visuaalsuse osale kujundliku keele mõistmisel pööratakse keele-alastes uuringutes üha enam tähelepanu. Hakatuse tegid selles vallas juba ligi aastakümme tagasi kognitivistid-psühholingvistid Raymond W. Gibbs Jr, Sam Glucksberg, Cristina Cacciari, Rachel Giora jt.

Mida tuleks aga täpsemalt mõista fraseoloogias paljukasutatud mõiste piltlikkus

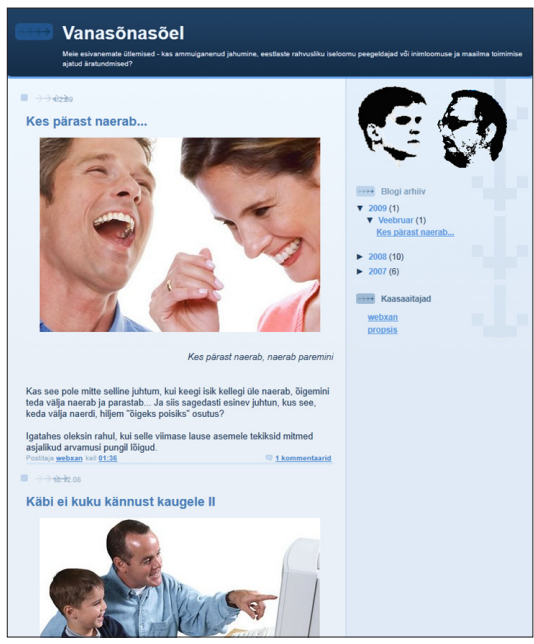
all? Fraseologismide uurimises pikka aega juhtkohal olnud saksakeelses teadustöös (vt Burger 2003) eristatakse kaht mõistet: üldisemas tähenduses kasutatav Bildlichkeit ehk piltlikkus ja kitsamas tähenduses Bildhaftigkeit ehk piltlikkus kui visuaalsus, kujundlikkus. ${ }^{4}$ Kujundlikkuse all tuleb mõista keelemärgi omadust ärgitada visuaalset kujutlusvõimet (e visualiseerimisvõimet). Seega suudetakse endale meeleliselt midagi ette kujutada. Teatud sõnad ja väljendid assotsieeruvad paratamatult mingi konkreetse situatsiooniga, kuna neil on tegelikkusega hõlpsalt mõistetav seos. Tuginedes enda ja oma kolleegide korraldatud psühholingvistilistele eksperimentidele on kognitiivse suunaga psühholingvist R. W. Gibbs Jr väitnud, et motiveerivad kujundid on psühholoogiliselt tõesed, sest katsete tulemused osutavad motivatsiooni kognitiivsele tõelisusele (cognitive reality of motivation) (2002: 452).

Nii ongi osade idioomide koosseisu kuuluvad sõnad ja väljendi enda otsene tähendus sedavõrd piltlikud, et kogu sündmus on ettekujutatav visuaalkonkreetsena. Tekkivaid kujundeid nimetavad Dmitri Dobrovolski ja Anatoli Baranov kvaasivisuaalseteks, ehk sellisteks, mida kõnelejad võivad teatud olukordades teadlikult kirjeldada ja neist n-ö tõukuda, ning mis võivad (aga ei pruugi) olla seotud vastavate idioomide aktuaalsete ehk tegelike tähendustega (Baranov \& Dobrovolski 2008: 112). Samuti võib kujutamisega seotud tegevus isikuti ja kasutamisseoseti erineda. Teisisõnu: inimeste kujutlused võimaldavad fraseoloogilise tähenduse erisugust meelelist kogetavust ning pole seega n-ö etteantud, vaid lubavad erinevaid individuaalseid tõlgendusi.

Mentaalsete kujundite osatähtust kujundliku keele mõistmisel ja omaksvõtul on viimastel aastatel üritatud jätkuvalt välja selgitada. Selleks on korraldatud arvukalt teste eelkõige seesuguste katseisikute seas, kes mingi teise 
keele valdajana õpivad süvendatult inglise keelt. Kuigi metoodika pädevate järelduste tegemiseks on alles arenemisjärgus, näitavad testid üheselt, et kujundite mõtestamine on suuresti individuaalne. Nagu eksperimentide tulemused osutavad, hõlbustab visualiseerimine oluliselt täiesti tundmatu idioomi mõistmist (Boers jt 2009).

On selge, et kujundliku keele mõistmiseks ei piisa üksnes teise keele ükskõik kui heast valdamisest. Kognitivistikast pärinevate universaalsusele pretendeerivate mudelite kõrval, mis tuvastavad metafoori kui keskse kujundi, eeldab keelemõistmine ka kultuurilise konteksti adumist. Selle-alase vajakajäämise korral võib visualiseerimine kui vihje aidata fraseoloogilist kujundit mõtestada. Samas, kuigi mõistestamist teadlikult suunatakse (või vähemalt üritatakse seda teha), on vastuvõtt suuresti kognitiivne, st tähenduste konstrueerimine on individuaalne. Nagu on ilmnenud katsetest, on täielik konsensus tähenduste osas äärmiselt harukordne (Szczepaniak \& Lew 2011).

Siinkohal tooksin näiteid, kus fraseologismi või vanasõna sisu on proovitud edasi anda visuaalsete vahenditega.

Näiteks leidsin meelelahutuslikust internetikeskkonnast iseloomuliku nimega "Mängukoobas - ajaviiteurg" - tekstita fotomontaaži, mille all olevas kommentaaris (mis ei ole mõeldud pildi osana) võib sisalduda osutus tuntud fraseologismile: See on ideaalne kostü̈̈m. Sammud maskeraadi poole! Nüüd saan ma aru miks öeldakse: "Ta on hunt lambanahas".”

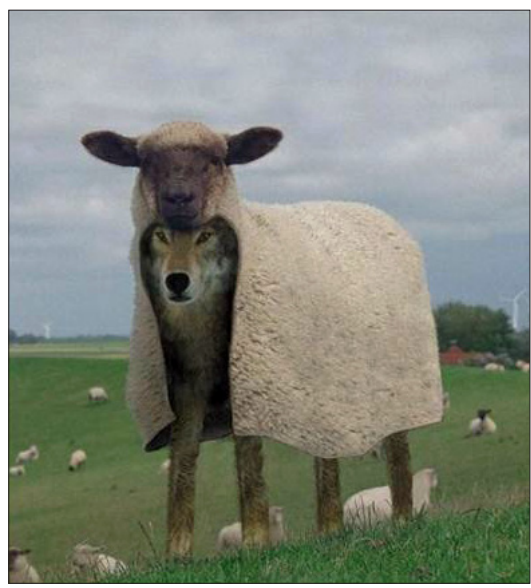

Foto 2. http://mangukoobas.lahendus.ee/id/7/action/full_media/media_id/289486/.

See foto on ilmekas näide fraseologismide piltlikkusest ja nende visualiseerimisvõimalustest. Samuti ilmestab selles näites sisalduv kommentaar inimeste 
arusaamu fraseologismi aktuaalsest tähendusest ehk tegelikust tähendusest. ${ }^{5}$ On selge, et lisaks fraseoloogilisele tähendusele sisaldab kujundlik üksus ka lähtekohti visuaalseteks kujutlusteks, mis võivad aidata mõistmisele kaasa ühelt poolt konkretiseerides, kuid teisalt tuues sisse tähenduselemente, millel pole midagi ühist fraseoloogilise tähendusega.

Teine näide ilmestab vanasõna Käbi ei kuku kännust kaugele kasutamist eestikeelse pealkirja või kommentaarina, mis võtab ilmekalt kokku ingliskeelse tekstiga (I wanna be just like dad when I grow up) plakatil kujutatu. Visualisatsioon ei ole seotud väljendi sõnasõnalise sisuga (käbi-känd), vaid on pigem mentaalne - seega kujundlik (figurative), mitte otsene (literative) visualiseering. Seega leiab kinnitust psühholingvistide tees, et fraseoloogilised keeleüksused on seesugused mentaalse leksikoni üksused, mis alluvad hõlpsalt tõlgendamisele. Seejuures ei saa rääkida ühest ja õigest tõlgendusest. Visuaalsete kujutiste kodeerimise kõrval võib rääkida ka dekodeerimisprotsessist.

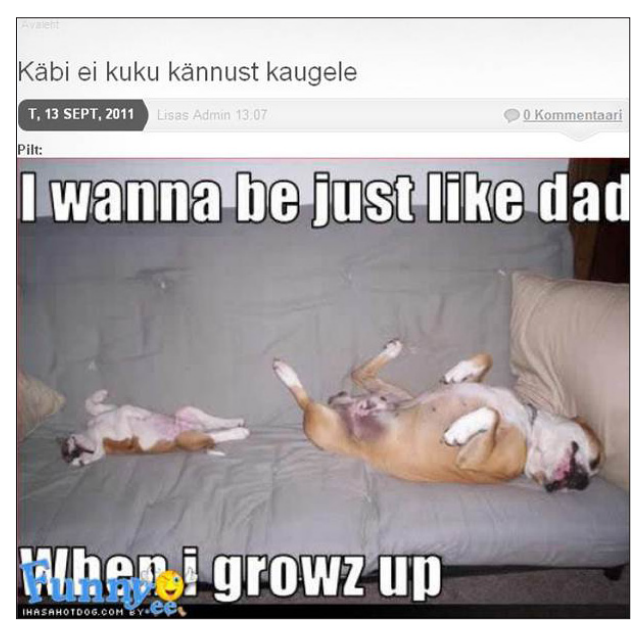

Foto 3. http:/ / funny.ee/node/13.

\section{Demotivaatorid kui visuaalne huumor internetis}

Demotivaatorites väljendub huumor enamasti vähem või rohkem koomiliste või lihtsalt iseäralike fotojäädvustuste või -montaažide (või ka fotokujutise manipuleerimise) ja nende juures esitatud pealkirja ja nn kommentaari vastuolus, kuna tekst on rõhutatult filosoofiline või äraspidiselt moraalitsev-pedagoogiline. Tulemuseks väljanaermine, pilkamine, parodeerimine. Selline äraspidisus 
(kokkusobimatus) ehk "tees versus antitees" struktuur ongi demotivaatorite olemus, millele osutab nende nimetuski - innustamise/motiveerimise asemel iroonia. Demotivaatorite puhul on iseäranis iseloomulik piltkujutise autonoomsuse puudumine - see esineb kombineeritult verbaalse sõnumiga. Kuigi piisaks ainult pildist, mis on tegelikkuse mingi aspekti jäädvustus või jäädvustuse töötlus, antakse sõnumi tegelik sisu edasi just sõnades.

Demotivaatoritel on ühisosa omaaegse nõukogude ühiskonnas hoogsalt viljeldud plakatikunstiga, millel pidi küll siiski olema motiveeriv funktsioon. Ka tänapäeval kasutatakse tollaseid poliitilisi plakateid või nende motiive ja luuakse uusi fotokollaaže/montaaže, mille eesmärk on algsest hoopis erinev. Piltkujutis, mis oma olemuselt on jäädvustus, võib sel kombel eksisteerida ka konstruktsioonina. Ehk nagu on osundanud M. Laaniste: esimesel juhul on tegu n-ö asjaga iseeneses, teisel konventsionaalse ilminguga. Ent pilt võib olla ka nende kahe sulam (2005: 617-618).

Kahtlemata on demotivaatorite näol tegemist rahvusvahelise, nn netifolkloori või netihuumorina määratletava ilminguga (Vinnikov 2010). Määravaks saab just asjaolu, et neid levitatakse anonüümses internetikeskkonnas. ${ }^{6}$ Kuigi selliseid postreid võib leida ka netimeediast (uudisteportaalide meelelahutusküljed), on Eestis seesugune materjal leitav eelkõige eriotstarbelistel huumorisaitidel. Kasutaksin viimastel leiduvate postrite kohta määratlust demotivatsioonita demotivaatorid. Vene uurijatelt (vt Golikov \& Kalašnikova 2010: 127) pärinev termin annab väga hästi edasi seda tüüpi visuaaliate erinevust algsena mõeldust.

Tunnuslikud on selliste meelelahutuskeskkondade nimetused: naerapooleks. com, vimka.delfi.ee (populaarse uudisteportaali meelelahutuslisa), aegmaha. com, naljad.ee, funny.ee, fail.ee (alapealkirjaga "Naljakaimad läbikukkumised ja õnnestumised"), hullumaja.com.

Seesugused keskkonnad sisaldavad üldjuhul üpris mitmekesist materjali: nii fotosid, videosid kui ka anekdoote. Fotode alt leiab enamasti lihtsalt naljakaks peetavate seikade jäädvustusi, aga ka mainitud demotivaatoreid, üldpealkirjaks sageli "Naljakad pildid". Kiire pilguheit loetletud saitidele osutab, et ülekaalus on siiski verbaalne huumor, st anekdoodid (eestikeelsed):

fail.ee sisaldab üksnes pilte ja videosid, sh 676 "eesti feili", 1184 "välismaist feili";

naljad.ee 346 pilti, 1122 anekdooti, 59 videot;

vimka.delfi.ee 478 fotot, 27771 anekdooti, 116 videot.

Rühmitamine näib kõigil mainitud netilehtedel olevat üsna ühetaoline. Ühe saidi näitel (naerapooleks.com) tooksin piltide alusel eristatavad temaatilised kategooriad: arvutid, loomad, kuulsused, inimesed, sport, autod. Levinum on 
siiski jaotamine ajalise näitaja (uuemad, vanemad) või reitingu alusel. Enamasti on kõigis sellistes keskkondades välja pakutud ka kommenteerimise ja hindamise võimalus. Tekkivad kategooriad on ühtlasi ainese üheks rühmitamisaluseks: "enimsoovitatud", "kõrge hindega", "kommenteerituimad", "parimad", "populaarseimad", "lemmikuimad", "vingemad", "kuum". Samuti tavatsetakse rühmitada materjali lisandumise põhjal: "uued", "uudised", "viimati lisatud". Leiduvad rubriigid seesuguste lakooniliste nimedega nagu "muud naljad / naljakat", "igasugust", aga ka "see on äge", "see on hirmutav", "fuu". Hetke populaarseim on üldjuhul saidi avalehel, st alati esimesena kättesaadav.

Loomulikult on kõik sellised internetilehed esindatud sotsiaalsetes võrgustikes Facebook ja Twitter, mis võimaldab postrite jm ilmingute linkimist ja populaarsemate materjalide hoogsat levitamist.

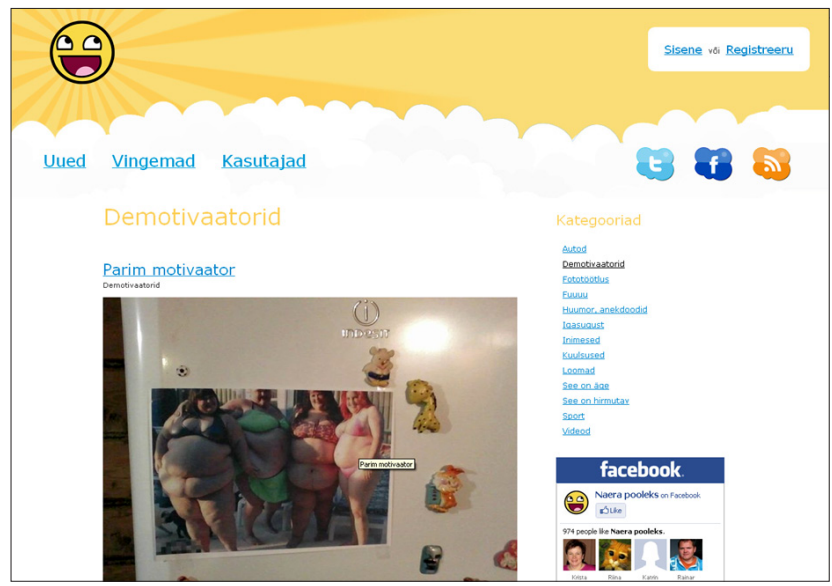

Foto 4. Meelelahutuskeskkond naerapooleks.com

Kuigi on selge, et pildiline kommunikatsioon on loomult universaalne, keelte ja kultuuride ülene, ning sõnalise osa lisandumisega peaks tekkima mõistmises teatav tõrge, on internetis levitavate ilmingute puhul keele osatähtsus tänapäeval näiliselt peaaegu olematu. Samas, nagu korduvalt märgitud, on arusaam visuaalsuse universaalsusest tegelikult suhteline - mõistmine võib kultuuriti vägagi erineda. Universaalse mõistmise olematuse näidetena tooksin kolm silma jäänud kvaasi-demotivaatorit, mis esindavad kohalikke poliitikuidarvamusliidreid (fotod 5-7). Seesuguseid nalju suudab enamasti mõista vaid kohalikke olusid hästi tundev inimene. 


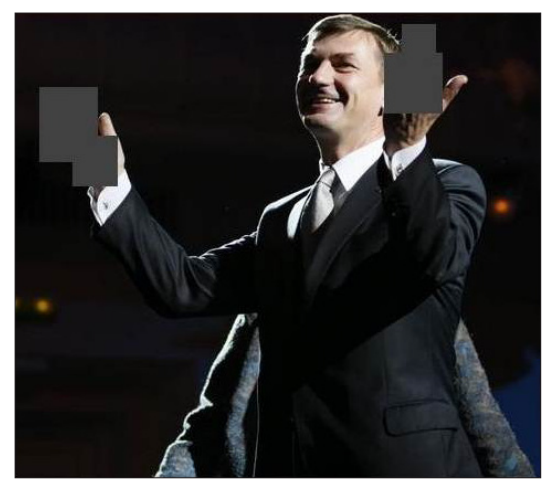

Foto 5. EV peaminister Andrus Ansip: http: / / naerapooleks.com/post/1168.

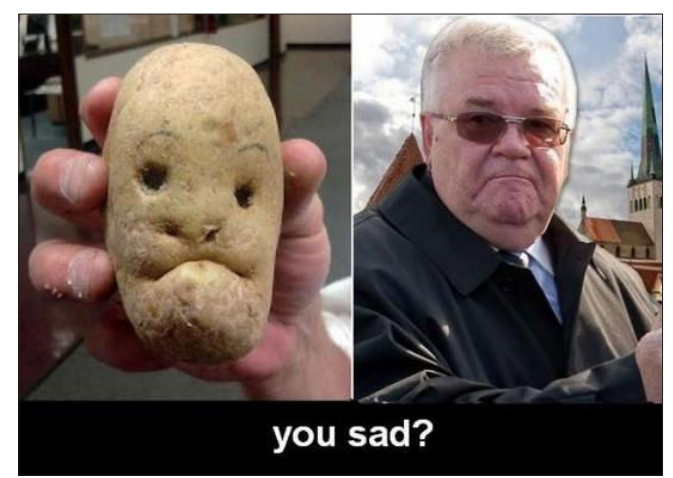

Foto 6. Tallinna linnapea Edgar Savisaar: http: / / naerapooleks.com / post/ 1088.

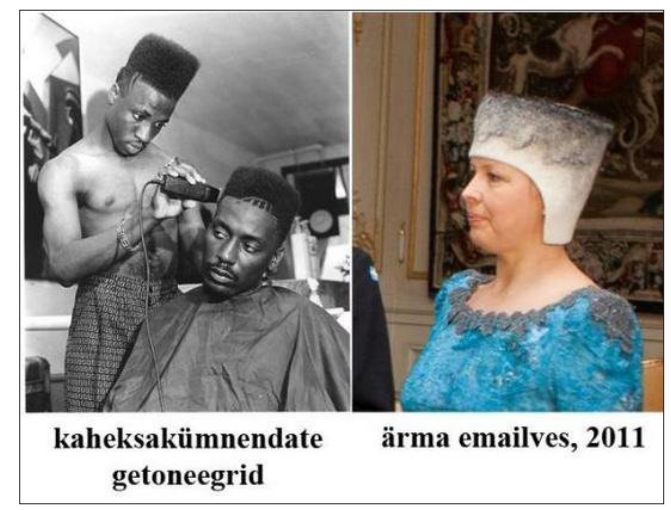

Foto 7. EV presidendi abikaasa Evelin Ilves: http: / / naerapooleks.com/post/1071.

Seega leidub eelnimetatud huumorisaitidel küll kohaliku ainese näiteid, kuid üldiselt on siiski tegemist rahvusvahelise materjali levitamisega. Torkab silma, et kolmeosalise struktuuriga, nn tõelisi demotivaatoreid kohtab harva. ${ }^{7}$ Seega on üsna ootuspärane, et ka eestikeelsete fraseologismide või muude traditsiooniliste väljendite kasutamist tuleb ette haruharva. Kui anekdoodid esitatakse emakeelsena, siis visuaalse huumori puhul, kus valitseb internetis ringlev materjal, ollakse selgelt originaalitruud, st piltide puhul jäetakse alles algne ingliskeelne (või venekeelne) tekst. Siin-seal on üritatud postritel esinevat teksti ka tõlkida, vähesel määral esineb tõlgendamist, nt oma kultuuri ja keelde kuuluvaga asendamist. Internetihuumori uurijad Limor Shifman ja Mike Thelwall on sedastanud, et seesugune suundumus on oma olemuselt universaalne, sest 
"tugeva globaalse aspektiga meemide paljunemisega kaasneb teataval määral glokaliseerumist" (2009: 2576). Kuigi rangelt n-ö tehniliselt võttes puuduvad veebimaailmas piirid, võivad keelelised ja kultuurilised seigad siiski mingite üksnes internetis sündinud ilmingute laiemat levikut takistada.

Kui rääkida Eestis esinevatest üksnes demotivaatorite esitamisele pühendunud internetikeskkondadest, oli 2011. aasta keskpaigani olemas ka eestikeelne üksnes demotivaatorite loomisele ja esitlemisele keskendunud veebileht http:// demot.ee/. Tänaseks on see internetisait oma tegevuse lõpetanud, mistõttu järgnev on pigem 2011. aasta kevade hetkeseisu kajastus kui seal leidunud postrite süvaanalüüs.

Nimetatud lehel sai olemasolevaid demotivaatoreid vaadata, kuid ka uusi postreid lisada. Selleks pakuti ka võimalust laadida alla demotivaatorite tegemiseks vajalik tarkvara. Välja oli töötatud ka nn eeskiri, millega püüti aktiivset kasutamist reguleerida. Nii olid keelatud järgmised tegevused: organisatsioonide ja liikumiste propaganda, piltide kasutamine, mis kutsuvad esile vaid negatiivseid emotsioone või rikuvad üldisi eetilisi norme, kirjavigu sisaldavad materjalid, piltide teistkordne kasutamine.

Tegelikkuses on teine nõue üpris vabalt tõlgendatav ja kolmas, ortograafiat puudutav tihtipeale eiratav, sest vigane kirjaviis on netikeskkonnas üsna tavaline. Käsitletava saidi puhul torkas silma seegi, et märkimisväärne osa postritest oli vene päritolu ning eestikeelne vastendamine sai sageli teoks ortograafiavigade hinnaga.

Rubriigist "Parimad" võis vähesel määral leida ka ütlusfolkloori: vanasõnu, tsitaate, ütlusi, tunnuslauseid sisaldavaid postreid. Taas oli kasutusel peaasjalikult rahvusvaheline aines, ehk siis internetimeemid, mida oli aga kohati üpris õnnestunult n-ö kohandatud. Nagu juba mainitud, leidus vähesel määral ka päris algupärandeid, st selgelt Eesti päritolu ainest. Siinkohal toon vaid mõned ilmekamad näited eesti vanasõnade kasutamisest:

- Küsija suu pihta ei lööda! > EV 5181 Küsija suu peale ei lööda.

- $\quad$ Ühe õnn on teise õnnetus. > EV 14733 Ühe õnn võib olla teise õnnetus.

- Nälg paneb karu puu otsa ronima ja meest varastama, kuid viimasel on ka teisi võimalusi. > EV 7707 Nälg sunnib karu käppa imema. EV 7679 Nälg ajab lapsed vargile. 

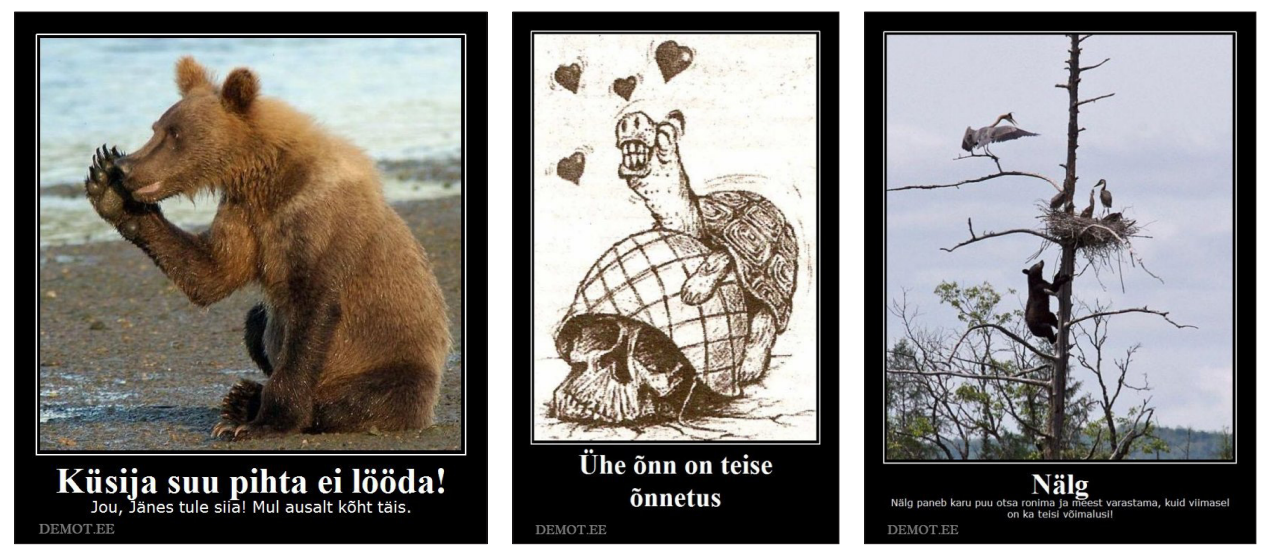

Fotod 8-10. Demotivaatorid eesti vanasõnade ja ütlustega.

Need eesti vanasõnu sisaldavad demotivaatorid on suurepärased näited inimeste loomingulisusest. Seejuures on tähelepanuväärne, et kasutatakse ka suhteliselt vähetuntud vanasõnu (karu ja nälja näide).

Otseselt Eesti-temaatikaga seotud ingliskeelset lausungit Estonian girls they are hot! on võimalik tõlgendada tegelikult ka vene anekdoodist pärineva fraasi gorjachie estonskije parni ehk kuumad eesti poisid (st aeglased) analoogia alusel loodud variandina, seega tsitaadina, mida on täiendatud ühe sõna väljavahetamisega.

Toodud näidete puhul on täheldatavad mõningad erinevused verbaalse osa kujutamises. Kui kaks esimest vanasõnanäidet on tekstina üsna vabalt tõlgendatavad, siis kolmas ja neljas osutavad üht kindlat verbaalse sõnumi kujutamise moodust, nimelt visualiseeritakse see sõnasõnalt (otseselt). Seega on kujutatu esitatud tekstiga tugevalt seotud. Ent kui postri anonüümne autor on oma arusaamade kujutamisel vaba, siis mõistmine vastuvõtja poolt ei saa olla üheselt määratud, sest ka etteantuse puhul on teadupärast võimalikud erinevad tõlgendused.

\section{Visuaalne huumor kui poliitilise satiiri avaldumiskoht}

Loomulikult ei piirdu seesuguste postrite esinemine üksnes meelelahutussaitide ja sotsiaalsete võrgustikega, neid kohtab ka erinevates internetikogukondades, kes on koondunud oma foorumitesse või haldavad kodulehti. Samuti leiab arvestataval hulgal visuaalset huumorit veebipäevikutest. Peaaegu võimatu on 
teha üldistusi, sest ülikiiresti vahelduvas internetikeskkonnas on keeruline saada isegi korralikku ülevaadet selles vallas toimuvast. Jagan siinkohal vaid mõningaid tähelepanekuid oma uurimistööga seoses.

Naastes arutluskäiguga interneti visuaalse kommunikatsiooni võimaluste juurde, paistab erinevalt eeltoodud näidetest juba põgusal esmavaatlusel foorumite-blogide puhul silma, et foto- ja videotöötluste ${ }^{8}$ objektidena domineerivad siin kohalikud karismaatilised juba omamoodi legendi staatuses poliitikud Tallinna linnapea Edgar Savisaar ja peaminister Andrus Ansip. Parodeerimise aluseks võetakse tavaliselt mingi hetkeline vääratus, kas pentsik seik või väljaütlemine, mida tunnustatud poliitikutelt kui avaliku elu tegelastelt näib lausa oodatavat. Äärmiselt populaarne on valimisreklaamide parodeerimine (fotod 11-13). Neis sisalduvad lubadused annavad ainest mitte üksnes väljendite-tsitaatide, vaid ka visuaalse huumori tekkeks. Iseäranis hõlpsalt saavad parodeerimise sihtobjektiks plakatid ja videod, milles alahinnatakse valijaid. Seega saab postritel kujutatu alusel rääkida ka inimeste poliitilisest meelsusest. Siinkohal toodud näidete najal võib tõmmata paralleele omaaegse poliitilise plakatikunstiga. Erinevus on peamiselt eesmärgis - tollane plakatikunst oli midagi hoopis muud kui meelelahutus. Ent selline kõrvutus osutab pigem tänapäeva visuaalse huumori erinevatele avaldusvormidele - see võib lisaks meelelahutuslikule olla ka satiiriline. Ning see teravik ei ole suunatud kellegi pihta kuskil kaugel, vaid omaenda kangelaste-antikangelaste suunas. Seega ollakse praegu foorumites, blogides jm varasemast sotsiaalselt aktiivsemad, ei piirduta üksnes meelelahutusega. Poliittemaatika, iseäranis kohalike poliitikute silmatorkavale populaarsusele digitaalses huumoris on osutatud ka laiapõhjalisema analüüsi tulemusena (Shifman 2007: 199).

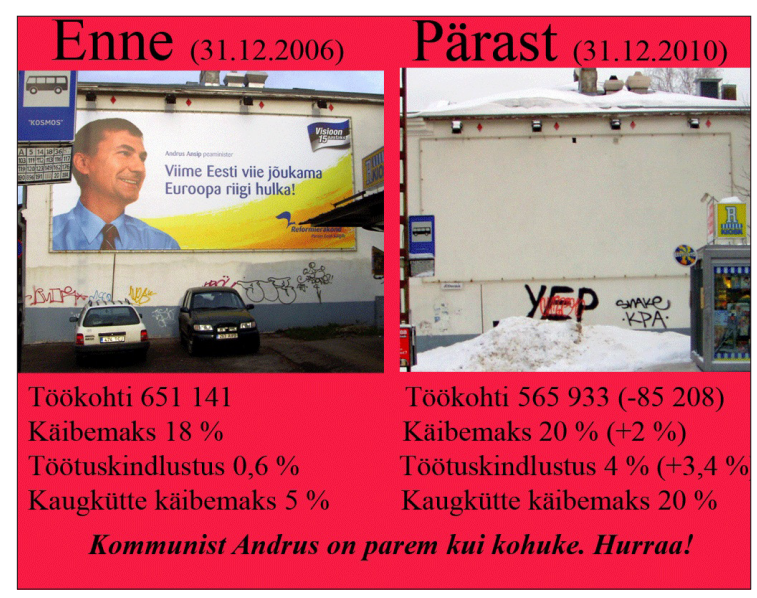

Foto 11. http: / / virgokruve.wordpress.com/2011/08/08/euroopa-joukate-riikide-edetabel-ehkkellest-tuleb-mooduda-viie-rikkama-hulka-joudmiseks /. 


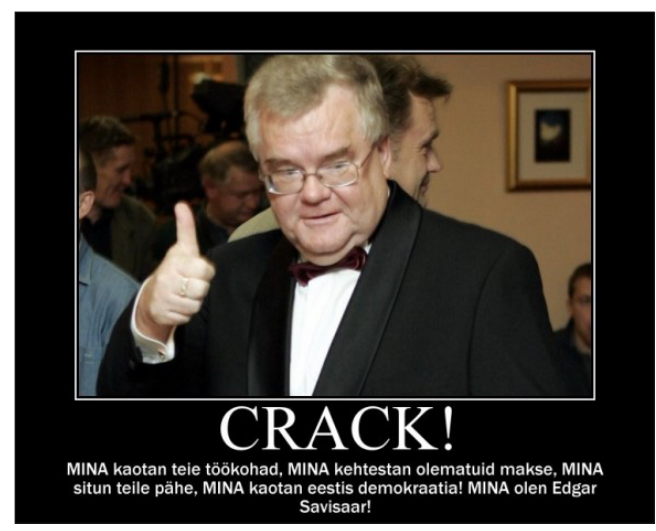

Foto 12. http: / / reg666.blogspot.com/2010/12/ konspiraator.html.

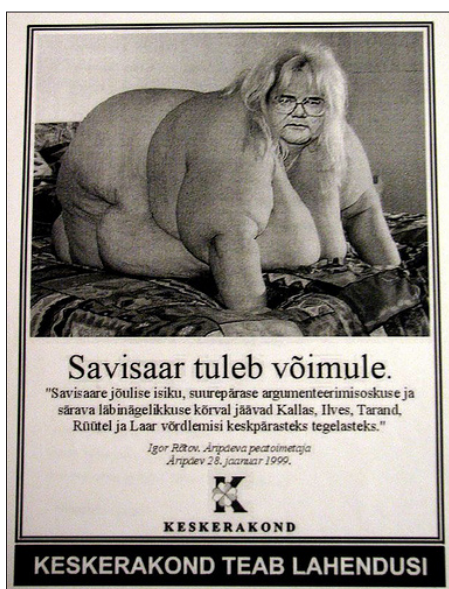

Foto 13. http: / / voyag.blogspot. com / 2006 / 05 / ripev-savisaar-tuleb-vimule-ps.html.

Tallinna linnapea poliitilis-majanduslik orienteeritus idanaabrile on paljudes fototöötlustes üks kesksemaid naeruvääristamise teemasid. Sama inimest sobitatakse tihtipeale ka ajaloolisse konteksti, kõrvutades teda negatiivsete liid-

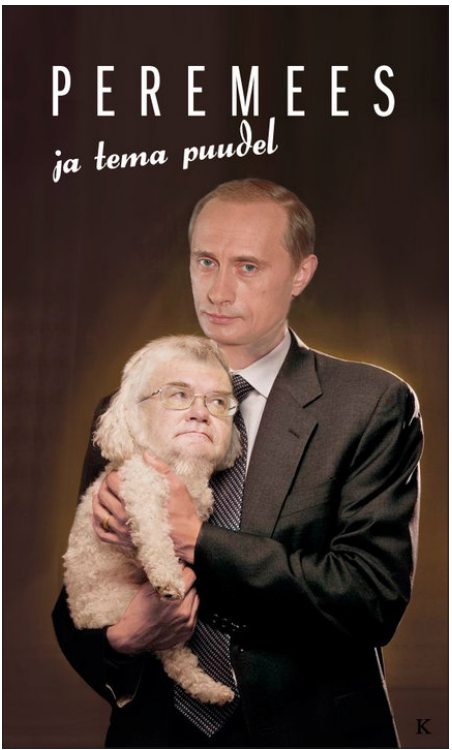

Foto 14. http://usk-lootus-armastus.blogspot.com / 2010/04/peremees-ja-tema-puudel.html. rite näidetega minevikust (Stalin, Hitler), aga ka mõne naaberriigi juhiga tänapäevast (Putin) (foto 14). Paralleelid ei ole sugugi meelevaldsed, ainest on saadud kohati absurdilähedasest tegelikkusest. Samas on tegemist äärmiselt lokaalsete, tugevalt kohaliku taustsüsteemiga seotud ilmingutega, mis jäävad väljaspool Eestit arusaamatuks. Siinkohal ilmutab end taas huvitav tõsiasi, et kuigi traditsiooniliselt peetakse piltide kommunikatiivsust esmapilgul verbaalsusest universaalsemaks, ilmneb lähemal uurimisel sageli, et universaalne arusaadavus toimib siiski kultuurikonteksti piires (Laaniste 2005: 618). Selge on seegi, et nii kujundliku keelekasutuse kui ka visuaalset keelekasutust esindavate piltkujutiste mõistmiseks ei piisa üksnes teise keele kui sellise ükskõik kui heast valdamisest. Nagu eespool märgitud, ei pruugi ka samas kultuuriruumis elavad inimesed mõista kujundlikkust või piltlikkust ühtmoodi. 
Lähemalt vaadeldes ilmneb, et ütlustena käsitletavaid saatetekste esineb poliitikuid pilavates visuaaliates vähe, pigem saab rääkida lööklausetest (Crack!; Keskerakond teab lahendusi!; Tehtud!; Euro tuleb!).

Valimisreklaamide kõrval on teiseks levinuimaks töötluste allikmaterjaliks märgilise tähenduse omandanud filmide tegelased ja kinokultuuri juurde tänini käivad plakatid. Sellistel juhtudel kasutatakse poliitiku näopilti hästituntud filmikangelase asemel (sagedamini sellistest kultusfilmidest nagu "Superman", "Star Trek", “Terminaator") (fotod 15 ja 16).

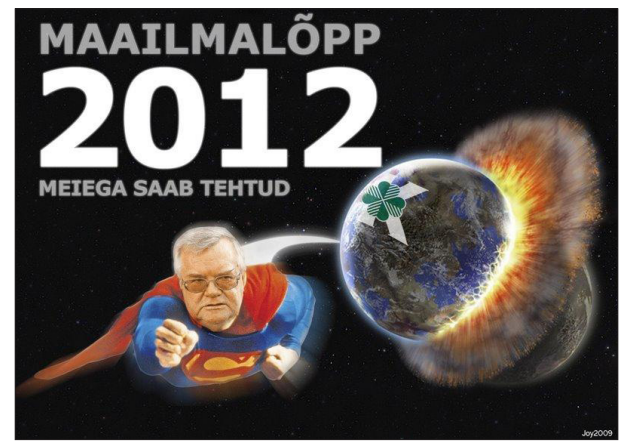

Foto 15. http:/ / mangukoobas.lahendus.ee/ id/7/action/full_media/media_id/270624/.

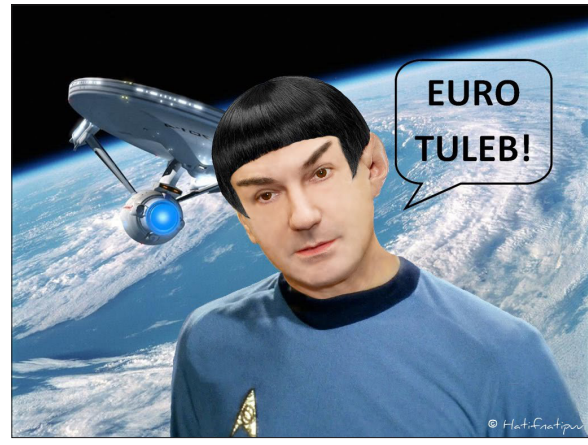

Foto 16. http://hatifnatipuu.blogspot. com/2010/07/avameelselt-eurost.html.

Poliitiliste tegelaste “ärakasutamine” annab tunnistust nende populaarsusest, kuigi see on pigem negatiivne, kriitiline tähelepanu (foto 17). Kuigi kaks enimkujutatud poliitilist tegelast esindavad maailmavaateliselt erinevaid poolusi, on neil ka ühisosa - populistlikud avaldused, mis annavad vastaspoolte esindajatele ainest pilamiseks (ja seda mitte ainult visuaalses huumoris, vaid ka anekdootides).

Toodud näidete toel söandan väita, et internetimeemina levivad visuaalse huumori ilmingud (näiteks demotiveerivad või analoogsel põhimõttel loodud postrid) on Eestis tehtud ja kavandatud peaasjalikult meelelahutusena, ent neis leidub silmatorkavalt ka poliitilist satiiri.

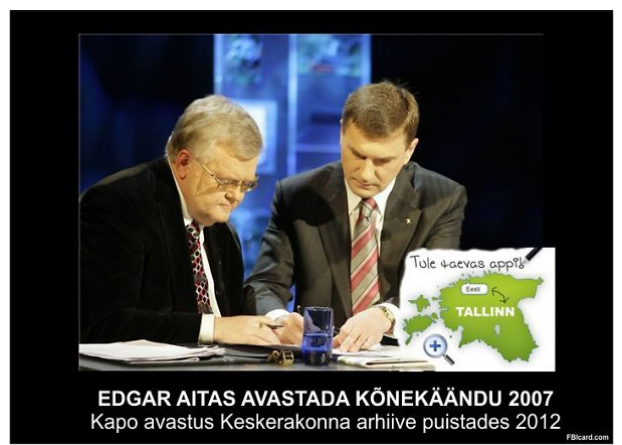


Sama tendentsi ilmutab ka teinegi populaarse internetimeemina toimiv žanr. Nagu eespool mainitud, pakub internet visuaalseks (sotsiaalseks) kommunikatsiooniks erinevaid võimalusi. Visuaalse netihuumori ühe liigina saab käsitleda ka üht kindlat multimeedia ilmingut - videosid. Seda tüüpi meelelahutuse sünonüümiks on ülekaalukalt saanud YouTube. Tänapäeval on laialt levinud komme jagada internetis YouTube'i videoklippide linke. See on sotsiaalse interaktsiooni üks vorme, mille osatähtsus nüüdisaegsete populaarsete kultuuriilmingute levitamises ja teadvustamises on märkimisväärne. Omamoodi tähendusrikkaks võib pidada seika, et 2007. aastal Eesti Kirjandusmuuseumi folkloristika osakonna korraldatud eesti koolinoorte folkloori kogumise aktsiooni tulemina laekus muu ainese hulgas noorte seas tollal populaarseid kilde/paroole/slängi, anekdoote jmt, mille kasutuskohaks märgiti eelkõige netisuhtlust (vt Baran 2010). Rubriigis "Naljad" märgiti enim kolme tsitaati ehk lendsõna, mis pärinevad kohalikelt poliitikutelt ning mille populaarsuses on "süüdi" just YouTube'i ülesriputatud videoklipid: Tule taevas appi!; Ei kommentaari!; Tehtud!

Kuigi lühikesevõitu lööklausete - millest kaks on lausa erakordselt napi sõnastusega, ilma igasuguse kujundlikkuseta ja üks traditsiooniline, ent nüüdseks iganenud ja tavakäibest taandunud retooriline hüüatus - menukuse taga on nende esitamine poliitikute poolt kummastavates situatsioonides, tuleb nende lausungite populaarsuse tegelikuks põhjuseks pidada hoopiski ühe kohaliku telekanali satiirisaadet. ${ }^{9}$ Kõik kolm pärinevad erinevatest allikatest - esimene valitsuse pressikonverentsilt (peaministrilt), teine televisiooni uudistesaatest (ebakorrektne sõnakasutus volikogu umbkeelselt poliitikult) ja kolmas valimisreklaamist (linnapea erakonna tunnuslausena). Ent nende populaarsuse tagamaad peituvad pigem katkeid pilamise eesmärgil esiletoonud populaarsel satiirisaatel, milles näidatud videolõigud riputati hiljem YouTube’i keskkonda. Kolmest kaks tsitaati on tänaseni ühtemoodi käibes nii noorte kui vanemate inimeste kõnepruugis, ilma et peaks viitama tsitaadi esmakasutajale. Ka annab Google'i otsing tulemuseks suurenumbrilisi vasteid: esimesele 297000 korral, teisele 112000 korral ning kolmandale 2100000 korral. Aktuaalsuse põhjuseid tuleb näha asjaolus, et ütlejatest kaks on kõigile tuntud juhtkohtadel poliitikud tänaseni.

Kas nende kolme ülipopulaarseks saanud napi, vähem või rohkem emotsionaalse ütluse põhjal võiks järeldada, et poliitikud noortele eriliselt huvi pakuvad, on siiski küsitav. Pigem hoopis vastupidi: nimelt leidus küsitluses ka noorte arvamusi, mille kohaselt kasutavadki poliitikud nn vaimukusi teadlikult oma populaarsuse tõstmiseks. Saksa fraseoloog Harald Burger on aga osutanud oma massimeedia vestluste uurimuses (1991: 50) otse-eetrisse minevate tele- ja raadiosaadetega seoses nende ehedusele ja spontaansusele, asjaolule, mistõttu needsamad poliitikud, kes tavapäraselt kaaluvad iga oma sõna, on 
sellisest võimalusest ilmajäetuna meie ees hoopiski emotsionaalsed ega suuda ennast alati kontrollida. Ent olenemata sellest, kas tegemist on kaalutletud või spontaanse käitumisega, võib tulemuseks olla igapäevakeelde juurduv väljend.

Toodud lendlausenäited esindavad ilmekalt visuaalse huumori ja fraseoloogia põimingut, kuigi siinkohal seisneb visualiseerimine üksnes asjaolus, et tsitaadid omandasid tuntuse just videoklipina esitamise järel. Arutlustest massimeedia ja televisiooni mõjuvõimu üle oleks aeg jõuda sügavamate aruteludeni. Nagu sissejuhatuses märgitud, elame visualiseerimise mõjukuse suurenemise ajal, sest meie nägemistaju on tunduvalt enam rakendatud kui muud tajud. Seega on ka visuaalne keel üha tähtsam. Verbaalse kujundkeele mõistmise alastes uuringutes, kus järjest rohkem pööratakse tähelepanu visualiseerimise kui mõtestamist hõlbustava faktori osakaalule, tõuseb selle aspektiga arvestamisest vaid tulu. Samuti aitab pildilisuse potentsiaali mõistmine kaasa seniste üpris jäikade arusaamade (kus pilti nähakse vaid illustreeriva elemendina) murendamisele.

\section{Kokkuvõtteks}

Mitte kunagi varem pole visuaalne külg oma tehniliste võimalustega olnud nii oluline kui praegu. Seega on üha enam põhjust uurida visuaalse keele ilminguid. Kuidas neid mõistetakse ja kas see erineb kuidagi oluliselt verbaalse sõnumi mõistmisest?

Fraseologismide kui kujundliku keelekasutuse uurimises on alati olnud kesksel kohal motivatsiooni ja sellega seonduva ikoonilisuse probleemistik. Seetõttu sobivad internetis levitatavad visualiseerimisele rajatud loovad ilmingud suurepäraselt ka piltlikkuse/kujundlikkuse mõistmise uurimiseks. Samuti on jätkuvalt üleval küsimus kultuuriliste taustaelementide rollist mitte ainult keele kujundlike üksuste, vaid ka visuaalsete ilmingute mõtestamises. Kahtlemata on sõnumi verbaalset ja visuaalset poolt siduvaid nähtusi, mis on hakanud oma elu elama internetis, hõlpsam mõista just sealses ümbruses, nende komplekssete seostega, mis on neil sealses keskkonnas. Seega on ilmne, et $n n$ virtuaalreaalsuses toimuvale uut tüüpi kontekstualiseerimisele tuleks pöörata üha enam tähelepanu. Ühtlasi on võimalik uurida, miks saavad internetikommunikatsioonis mingitest ilmingutest populaarsed meemid, teistest mitte. Ning sedagi, kas sellised nähtused on sõltumatud erinevatest keeltest ja kultuuridest või on see universaalsus siiski näiline. 


\section{Kommentaarid}

1 Artikkel on valminud sihtfinantseeritava teadusteema "Folkloori narratiivsed aspektid. Võim, isiksus ja globaliseerumine" (SF0030181s8) ja riikliku programmi "Eesti keel ja rahvuslik mälu" (EKKM09-150) raames.

${ }^{2}$ Mõnevõrra laiendatud väide selle kohta, et meem ja internet on mõlemad sarnased parasiidid, pärineb intervjuust, mille Blackmore andis Eesti ajalehele viis aastat pärast oma raamatu Meemimasin ilmumist. Selles selgitab ta oma teooriat interneti uuemate arengute valguses (vt Laurisaar 2005).

3 Parima sissevaate meeminduse temaatikasse saab internetisaidilt http://knowyourmeme.com/.

4 Eesti keeles on paraku need mõisted raskesti eristatavad: EKSSi järgi on piltlikkus '(visuaalse) pildina esinev, selle kaudu toimuv; kujundirikas, kujundlik', visuaalsus 'kujundiline e kujundeid sisaldav v kasutav'.

5 Termin aktuaalne tähendus pärineb Dmitri Dobrovolskilt ja Elisabeth Piirainenilt ning see tähistab kujundlikku tähendust (Dobrovolski \& Piirainen 2005: 14).

6 Demotivaatorite kasutamise eesmärkidega seoses väärib märkimist, et aastaid tagasi levis selliste humoorikate fototöötluste saatmine tuttavatele-sõpradele-kolleegidele meilitsi. Tegu on üksteise otsa lükitud posteritega (vormistatud Powerpointi esitlusfailina), millel oli mingi ühisnimetaja (nt Ideas; Relax). Eesmärgiks ei olnud neil juhtudel muu kui pelk meelelahutus.

7 Demotivaatorite kolmeosalise struktuuri kõrval võidakse rääkida ka neljandast osisest, milleks on postri must taust (vt nt Piekoti eritlust Piekot 2012: 192).

8 L. Shifman on kasutanud seesuguste fototöötluste demotivaatoritest eristamiseks nimetust maniphoto (Shifman 2007).

9 Analoogsetele suundumustele osutab oma artiklis poliitilise satiiri osatähtsusest tänapäeva Poolas ka Marta Dynel (2012).

\section{Internetinäidete allikad}

http://demot.ee/ - 13.09.2011.

http://fbicard.com/ - 13.09.2012.

http://funny.ee/ - 13.09.2012.

http://hatifnatipuu.blogspot.com - 13.09.2012.

http://mangukoobas.lahendus.ee - 13.09.2012.

http://naerapooleks.com - 13.09.2012.

http://propverb.blogspot.com/ - 13.09.2012.

http://reg666.blogspot.com - 13.09.2012.

http://virgokruve.wordpress.com - 13.09.2012.

http://voyag.blogspot.com - 13.09.2012.

http://en.wikipedia.org/wiki/ -13.09.2012. 


\section{Kirjandus}

Baran, Anneli 2010. Fraseologismide rollist Eesti koolinoorte keelekasutuses 2007. aasta koolipärimuse kogumisvõistluse põhjal. Tulnukad ja internetilapsed. Uurimusi laste- ja noortekultuurist. Tartu: EKM Teaduskirjastus, lk 95-124.

Baranov \& Dobrovolski 2008 = Baranov, Anatoli \& Dobrovolski, Dmitri. Aspekty teorii fraseologii [Fraseoloogiateooria aspektid]. Moskva: Znak.

Blackmore, Susan 1999. The meme machine. Oxford: Oxford University Press (doi:10.1515/ JISYS.1999.9.5-6.355). [Eesti keeles 2003. Meemimasin. Tallinn: Tänapäev.]

Boers, Frank \& Piquer Píriz, Ana María \& Stengers, Hélène \& Eyckmans, June 2009. Does pictorial elucidation foster recollection of idioms? Language Teaching Research 13,4, lk 367-382.

Burger, Harald 1991. Das Gespräch in den massenmedien. Berlin; New York: de Gruyter.

Burger, Harald 2003. Phraseologie. Eine einführung am beispiel des Deutschen. Berlin: Erich Schmidt.

Crystal, David 2006. Language and the Internet. Cambridge: CUP.

Dobrovolski \& Piirainen 2005 = Dobrovol'skij, Dmitrij \& Piirainen, Elisabeth 2005. Figurative language: cross-cultural and cross-linguistic perspectives. Amsterdam [etc.]: Elsevier.

Dynel, Marta 2012. Contemporary political humour. Polish Humour. Humour and Culture 2. Brzozowska, Dorota \& Chłopicki, Władysław (toim). Kraków: Tertium, lk 437-449. EV = Hussar, Anne \& Krikmann, Arvo \& Normann, Erna \& Pino, Veera \& Sarv, Ingrid \& Saukas, Rein (koost) 1980-1988. Eesti vanasõnad I-V. Monumenta Estoniae Antiquae III. Proverbia Estonica. Tallinn: Eesti Raamat.

EKSS = Eesti kirjakeele seletussõnaraamat I-VII. Tallinn: Eesti Keele Instituut, 19882007.

Gibbs, Raymond W. Jr. 2002. A new look at literal meaning in understanding what is said and implicated. Journal of Pragmatics 34 (4), lk 457-486 (doi:10.1016/SO3782166(01)00046-7).

Golikov \& Kalašnikova 2010 = Golikov, Aleksandr \& Kalašnikova, Alina. Demotivatorõ v Internet-kommunikatsij: genezis, smõsl, tipologija. Vestnik Harkovskogo gosudarstvennogo universiteta, Harkov: HU, lk 124-130.

Kress, Gunther 2003. Literacy in the new media age. London and New York: Routledge (doi:10.4324/9780203164754).

Laaniste, Mari 2005. Piltide ja kirja keelest. Keel ja Kirjandus 8, lk 617-629.

Laurisaar, Riho 2005. Inimest ei juhi jumal ega mõistus vaid müstiline meem. Intervjuu Susan Blackmore'iga. Eesti Päevaleht (http://www.epl.ee/news/kultuur/article. php?id=51007268 -13 . oktoober 2012). 
Piekot, Tomasz 2012. Pictorial representation of idioms in Internet humour. Laineste, Liisi \& Brzozowska, Dorota \& Chłopicki, Władisław (toim). Estonia and Poland. Creativity and tradition in cultural communication 1. Tartu: ELM Scholarly Press, lk 187-204.

Shifman, Limor 2007. Humor in the age of digital reproduction. International Journal of Communication 1 (2007), lk 187-209.

Shifman, Limor \& Thelwall, Mike 2009. Assessing global diffusion with web memetics: The spread and evolution of a popular joke. Journal of the American Society for Information Science and Technology 60 (12), lk 2567-2576 (doi:10.1002/asi.21185).

Szczepaniak, Renata \& Lew, Robert 2011. The role of imagery in dictionaries of idioms. Applied Linguistics 32 (3), lk 323-347 (doi:10.1093/applin/amr001).

Vinnikov 2010 = Vinnikov, Vladimir. Demotivatorõ. Žanr russkogo folklora (http://zavtra. $\mathrm{ru} /$ cgi//veil//data/zavtra/10/886/81.html - 13.09.2012).

Wikipedia. http://en.wikipedia.org/wiki/Motivational_poster - 13.09.2012.

\section{Summary}

\section{Visual humour on the Internet}

\section{Anneli Baran}

Keywords: Internet, demotivators, figurative expressions, humour, visualisation

This article focuses on the role of visual imagery in language understanding. It is commonly held that the use of phraseologisms is most characteristic to spoken language. However, today we are faced with a situation where the usage of written and oral language has blended (in e-mails, on-line communication, social network) on the Internet. Creative use of expressions, even if manifested in an exaggerated or inappropriate manner, may lead to interesting figures of speech. I am going to concentrate on a subgenre of so-called Internet memes - demotivational posters or manipulated photos which contain figurative expressions. Clearly, it is the creative context of the Internet that has given new life to figurative expressions. People are interpreting phraseologisms differently from a traditional vis-à-vis conversation when being engaged in spontaneous virtual communication. In addition, the iconic nature of the motivation involved in understanding figurative expressions makes it possible to use the phrases as a means of visualisation. That is why it is possible to confirm that phraseological units are remarkably more complex phenomena than simple reproducible linguistic units that do not contain metaphors. 